\title{
Electrochemical Applications of Electrolytes Based on Ionic Liquids
}

\author{
M.J. Neto ${ }^{a}$, R. Leones ${ }^{a}$, F. Sentanin ${ }^{b}$, J.M. S. S. Esperança ${ }^{c}$, M.J. Medeiros ${ }^{a}$, A. \\ Pawlicka $^{\mathrm{b}}$, M.M. Silva ${ }^{\mathrm{a}}$ \\ ${ }^{a}$ Centro de Química, Universidade do Minho, Campus de Gualtar, 4710-057 Braga, \\ Portugal \\ bInstituto de Química de São Carlos, Universidade de São Paulo, CxP 780, \\ 13560-970 São Carlos, SP - Brazil \\ 'Instituto de Tecnologia Química e Biológica, Universidade Nova de Lisboa, \\ www.itqb.unl.pt, 2780-157 Oeiras, Portugal
}

The potential utility of room temperature ionic liquids as electrolytes in current electrochemical applications has been explored. Hence, the electrochemical behavior of $[\mathrm{Ni}(\mathrm{tmc})] \mathrm{Br}_{2}$ complex at a glassy carbon electrode in the absence or in the presence of unsaturated halides in the ionic liquids, 1-ethyl-3methylimidazolium ethylsulfate, $\left[\mathrm{C}_{2} \mathrm{mim}\right]\left[\mathrm{C}_{2} \mathrm{SO}_{4}\right]$ and $\mathrm{N}, \mathrm{N}, \mathrm{N}-$ trimethyl-N-(2-hydroxyethyl) ammonium bis(trifluoromethylsulfonyl)imide, $\left[\begin{array}{lllll}\mathrm{N}_{1} & 1 & 1 & 2(\mathrm{OH})\end{array}\right]\left[\mathrm{NTf}_{2}\right]$, has been examined by cyclic voltammetry. It was observed that $[\mathrm{Ni}(\mathrm{tmc})]^{2+}$ complex is reduced in a reversible one-electron step and the electrogenerated $[\mathrm{Ni}(\mathrm{tmc})]^{+}$complex catalytically reduces the carbon-halogen bond of unsaturated halides.

The potencial use of natural ionic conducting polymer matrixes was also investigated. Samples of natural macromolecules-based electrolytes with the ionic liquid 1-ethyl3-methylimidazolium ethylsulfate, $\left[\mathrm{C}_{2} \mathrm{mim}\right]\left[\mathrm{C}_{2} \mathrm{SO}_{4}\right]$, were prepared and characterized. The preliminary studies carried out with electrochromic devices (ECDs) incorporating optimized compositions have confirmed that these materials may perform as satisfactory multifunctional component layers in the field of ECD-based devices.

\section{Introduction}

Environmental concerns motivate the search for novel efficient methods where less toxic fluid alternatives can replace the usually toxic or hazardous solvents. Room temperature ionic liquids (RTILs) may be considered an attractive alternative for reducing solvent emissions to the atmosphere comparatively to volatile organic solvents (VOCs) (1).

During the last decade, a large number of publications have appeared that deal with electrochemistry in ionic liquids due to their thermal stability, good conductivity, almost null volatility (2), wide electrochemical window, recyclability and non-flammability (3). Hence, there is currently interest in the use of those materials for a wide range of applications, namely in electrochemical synthetic processes (4) without any added supporting electrolyte and in the evaluation of the redox behavior of electroactive 
substrates $(5,6)$ as well as in others diverse electrochemical technologies such as, batteries, fuel cells, solar cells, photovoltaic devices and metal deposition (7).

In this work, we present some selected research involving current electrochemical applications of RTILs.

Hence, we have explored the potential utility of those media as electrolytes for electrosynthesis. The preliminary studies of electrochemical behavior of $[\mathrm{Ni}(\mathrm{tmc})] \mathrm{Br}_{2}$ complex at a glassy carbon electrode in the absence and in the presence of unsaturated halides in different RTILs has been examined by cyclic voltammetry.

We have also investigated the potentiality of RTILs as solvent-free electrolytes in natural polymer matrix. Samples of solvent-free electrolytes were prepared and characterized by ionic conductivity measurements, thermal analysis, and electrochemical stability.

\section{Experimental section}

$\underline{\text { Materials }}$

Ionic liquids. The ionic liquids used in this work were 1-ethyl-3-methylimidazolium ethylsulfate, $\left[\mathrm{C}_{2} \mathrm{mim}\right]\left[\mathrm{C}_{2} \mathrm{SO}_{4}\right]$ which was purchased from IoLiTec with a stated purity of more than $99 \%$ and N,N,N-trimethyl-N-(2-hydroxyethyl) ammonium bis(trifluoromethylsulfonyl)imide, $\left[\begin{array}{lllll}\mathrm{N}_{1} & 1 & 1 & 2(\mathrm{OH})\end{array}\right]\left[\mathrm{NTf}_{2}\right]$ which was synthetised with a purity better than $99 \%$ as described in a previous paper (8).

In order to reduce water and volatile compounds to negligible values, all samples were dried under vacuum $(0.1 \mathrm{~Pa})$ and vigorously stirred at moderate temperature $(330 \mathrm{~K})$ for at least a day. Coulometric Karl-Fischer titrations revealed levels of water, always below $300 \mathrm{ppm}$. This value is a conservative estimate that takes into account the uncertainty associated with the handling of the samples.

\section{Polymer electrolyte preparation}

Samples were prepared according to an optimized procedure described elsewhere by E. Raphael et al $(9,10)$.

\section{$\underline{\text { Measurements }}$}

Cyclic voltammetry. Cyclic voltammograms were carried out with the aid of an AUTOLAB model PGSTAT12 potentiostat-galvanostat. The data from the above experiments were acquired and stored by GPES 4.9 software, which controlled a data acquisition board installed in a personal computer.

Cyclic voltammograms were recorded in a three-electrode, two-compartment cell as described in earlier publications (11). The working electrodes were fabricated from 3mm-diameter glassy carbon rods press-fitted into Teflon shrouds to provide planar, circular working electrodes with areas of $0.07 \mathrm{~cm}^{2}$. Before use, the electrodes were cleaned with an aqueous suspension of $0.05-\mu \mathrm{m}$ alumina (Buehler) on a Master-Tex (Buehler) polishing pad. The counter electrode was a $\mathrm{Pt}$ spiral in the same compartment. The experimental reference electrode was a $\mathrm{Ag} / \mathrm{AgCl} / 3 \mathrm{~mol} \mathrm{dm}^{-3} \mathrm{KCl}$ in water, separated from the working electrode by a sinter and Luggin capillary. All solutions were deoxygenated with a fast stream of argon before each experiment. 
All potentials are quoted with respect to a $\mathrm{Ag} / \mathrm{AgCl} / 3 \mathrm{M} \mathrm{KCl}$ in water reference electrode (-0.036 vs SCE).

Polymer electrolyte characterization. The total ionic conductivity of the samples was determined by locating an electrolyte disk between two $10 \mathrm{~mm}$ diameter ion-blocking gold electrodes (Goodfellow, > 99.95\%) to form a symmetrical cell.

Samples of dry films were subjected to thermal analysis under a flowing argon atmosphere between -60 and $200{ }^{\circ} \mathrm{C}$ and at a heating rate of $5{ }^{\circ} \mathrm{C} \cdot \mathrm{min}^{-1}$ using a Mettler DSC 821e. Samples for thermogravimetric studies were prepared in a similar manner, transferred to open crucibles and analyzed using a Rheometric Scientific TG1000 thermobalance operating under flowing argon, between 30 and $700{ }^{\circ} \mathrm{C}$ and at a heating rate of $10^{\circ} \mathrm{C} \cdot \mathrm{min}^{-1}$.

The evaluation of the electrochemical stability window of electrolyte compositions was carried out under an argon atmosphere using a $25 \mu \mathrm{m}$ gold microelectrode.

Electrochromic devices with the configurations glass/ITO/ $\mathrm{WO}_{3} /$ electrolyte/ $/ \mathrm{CeO}_{2}-$ $\mathrm{TiO}_{2} / \mathrm{ITO} /$ glass were obtained by assembling the 2 pieces of coated glasses. The electrochemical measurements were performed with Autolab 302N with FRA 2 module.

\section{Results and Discussion}

Characterization of RTIL $\left[\mathrm{C}_{2} \underline{\operatorname{mim}]\left[\mathrm{C}_{2}\right.} \underline{S O}_{4}\right]$ as electrolyte in natural polymer matrix

Thermal behavior. The DSC results obtained with the polymer electrolytes based on gelatin and agar with $\left[\mathrm{C}_{2} \mathrm{mim}\right]\left[\mathrm{C}_{2} \mathrm{SO}_{4}\right]$ are illustrated in Fig. 1 and confirm that all the polymer electrolytes produced are totally amorphous. The amorphous nature of these electrolytes provides a clear advantage relative to the PEO based system (12), since the absence of crystallinity results in improvements in optical, mechanical and electrochemical behavior.
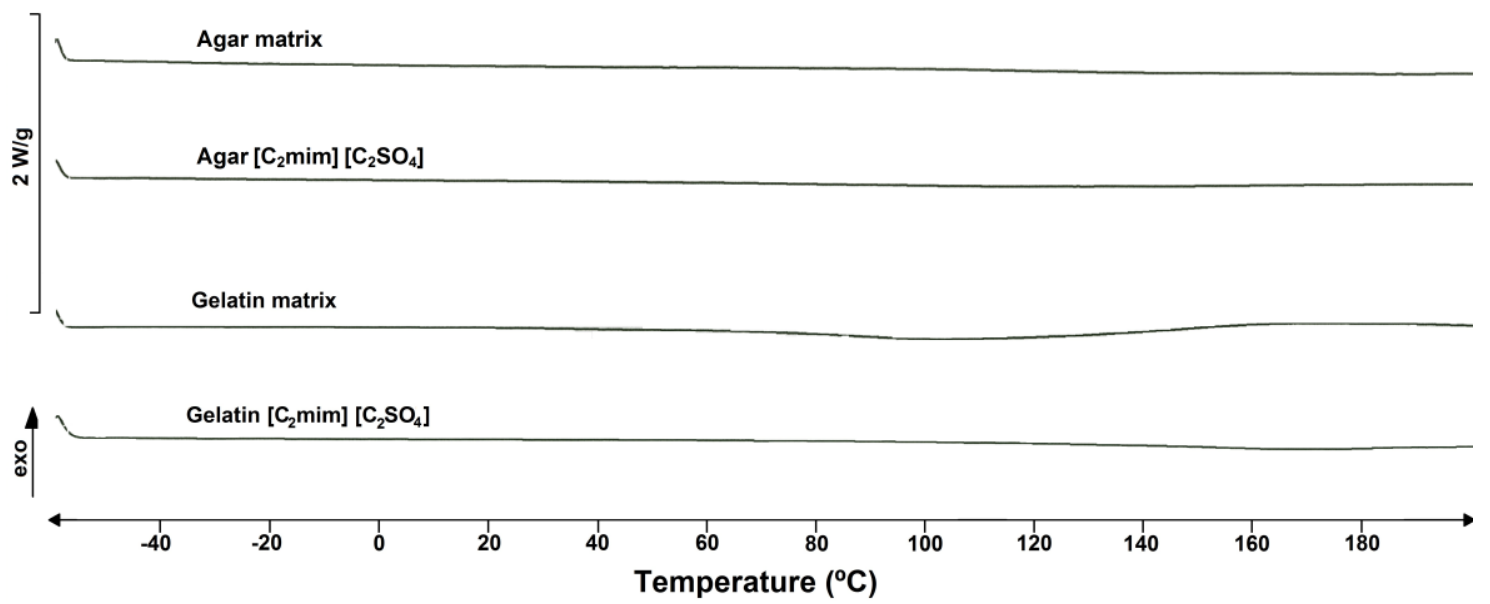

Figure 1. DSC curves of electrolyte systems.

The onset temperature of thermal decomposition was estimated by thermogravimetric analysis (Fig. 2) using extrapolation of the baseline and tangent of the curve of thermal events to identify the initiation of sample weight loss. In the region of $220-400{ }^{\circ} \mathrm{C}$, a film of agar showed a very accentuated mass loss of $65 \%$, which marks the decomposition of sample, and slowly continues as the temperature is 
increased up to $700{ }^{\circ} \mathrm{C}$. In the case of samples with ILs, the loss mass behavior as a function of temperature is different. The degradation process occurs on two stages for the agar based electrolyte with $\left[\mathrm{C}_{2} \mathrm{mim}\right]\left[\mathrm{C}_{2} \mathrm{SO}_{4}\right]$, assuming that the negligible initial mass loss observed $(<5 \%)$ is exclusively associated with the release of solvents, such as water adsorved or coordinated. The first stage starts at $200{ }^{\circ} \mathrm{C}$ for a mass loss of $90 \%$ and the second starts at $300{ }^{\circ} \mathrm{C}$ for a mass loss of $68 \%$, ends at $550{ }^{\circ} \mathrm{C}$ and slowly continues until $700{ }^{\circ} \mathrm{C}$. These stages are due to the agaropectin and agarose presence in the samples and the different interactions with IL. The remaining residue was $15 \%$ in mass of the starting materials, for agar and for the sample based on $\left[\mathrm{C}_{2} \mathrm{mim}\right]\left[\mathrm{C}_{2} \mathrm{SO}_{4}\right]$.

For the systems based on gelatin, the decomposition occurs up to $400{ }^{\circ} \mathrm{C}$, and slowly continues as the temperature is increased up to $700{ }^{\circ} \mathrm{C}$. The remaining residue was $20 \%$ in mass of starting material for gelatin and gelatin $\left[\mathrm{C}_{2} \mathrm{mim}\right]\left[\mathrm{C}_{2} \mathrm{SO}_{4}\right]$. TGA analysis (Fig. 2) is consistent with a minimum thermal stability of $200{ }^{\circ} \mathrm{C}$, a value considered acceptable for most applications under normal operating conditions.

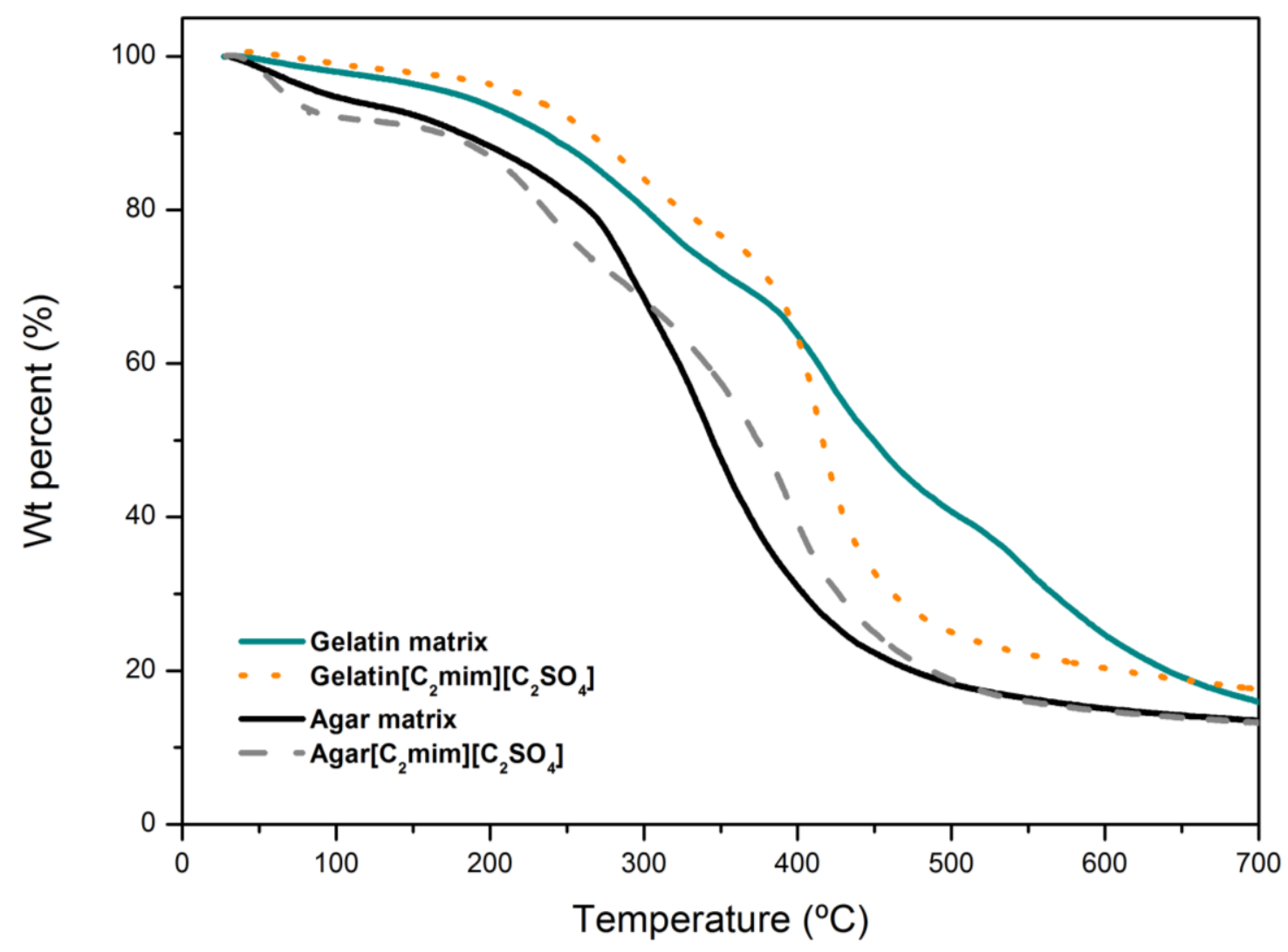

Figure 2. TGA curves of electrolyte systems.

Electrochemical properties. High ionic conductivity (higher than $10^{-5} \mathrm{~S} \mathrm{~cm}^{-1}$ ) is definitely one of the most important requirements that need to be fulfilled in a polymer electrolyte system if practical applications in electrochemical devices are envisaged.

The ionic conductivities of various polymer electrolytes over the temperature range from 25 to $105{ }^{\circ} \mathrm{C}$ are illustrated in Fig. 3. All samples exhibit non-linear variation of conductivity with temperature, which is typical of polymer electrolytes with predominantly amorphous morphology. For instance, while at $30^{\circ} \mathrm{C}$ the conductivity of the gelatin $\left[\mathrm{C}_{2} \mathrm{mim}\right]\left[\mathrm{C}_{2} \mathrm{SO}_{4}\right]$ is $\mathrm{ca} .9 .73 \times 10^{-5} \mathrm{~S} \mathrm{~cm}^{-1}$, at about $100^{\circ} \mathrm{C}$ it attains $2.37 \times 10^{-3}$ $\mathrm{S} \mathrm{cm}^{-1}$. This value is similar to the one reported by Singh et al (13) for the ionic liquid 
2,3-dimethyl-1-octylimida-zolium triflate (DMOImTf) in PEO electrolyte system but, higher than those reported by Vieira et al (14) for the gelatin based system. The conductivity of the electrolyte system with agar and $\left[\mathrm{C}_{2} \mathrm{mim}\right]\left[\mathrm{C}_{2} \mathrm{SO}_{4}\right]$ is $1.10 \times 10^{-5} \mathrm{~S}$ $\mathrm{cm}^{-1}\left(\mathrm{~T}=30^{\circ} \mathrm{C}\right)$. At $100^{\circ} \mathrm{C}$, this electrolyte exhibits a conductivity of about $7.24 \times 10^{-4} \mathrm{~S}$ $\mathrm{cm}^{-1}$. The differences in the conductivity values of the samples may be due to the type of matrix, its dielectric constant, viscosity, interaction with IL and molecular weight $(15,16)$. As expected, the incorporation of ionic liquids into the matrix increases the ionic conductivity over the entire temperature range investigated. The temperature dependence of the ionic conductivity was well-described by the Vogel-Tamman-Fulcher (VTF) equation in the temperature range of 25 to $100{ }^{\circ} \mathrm{C}$. The VTF expression implies that the main mechanism of ion conduction can be related to the free volume theory. The fitted values of the $\mathrm{E}_{\mathrm{a}}$ for gelatin $\left[\mathrm{C}_{2} \mathrm{mim}\right]\left[\mathrm{C}_{2} \mathrm{SO}_{4}\right]$ is $18.48 \mathrm{~kJ} \mathrm{~mol}^{-1}$, and for agar $\left[\mathrm{C}_{2} \mathrm{mim}\right]\left[\mathrm{C}_{2} \mathrm{SO}_{4}\right]$ is $24.30 \mathrm{~kJ} \mathrm{~mol}^{-1}$, which are in perfect agreement with the conductivity data. The $\mathrm{E}_{\mathrm{a}}$ values decrease with the addition of IL compared to matrix. This is in agreement with the fact that the amount of ions in polymer electrolyte increases, and the energy barrier to the ion transport decreases, leading to a decrease in the activation energy (17).

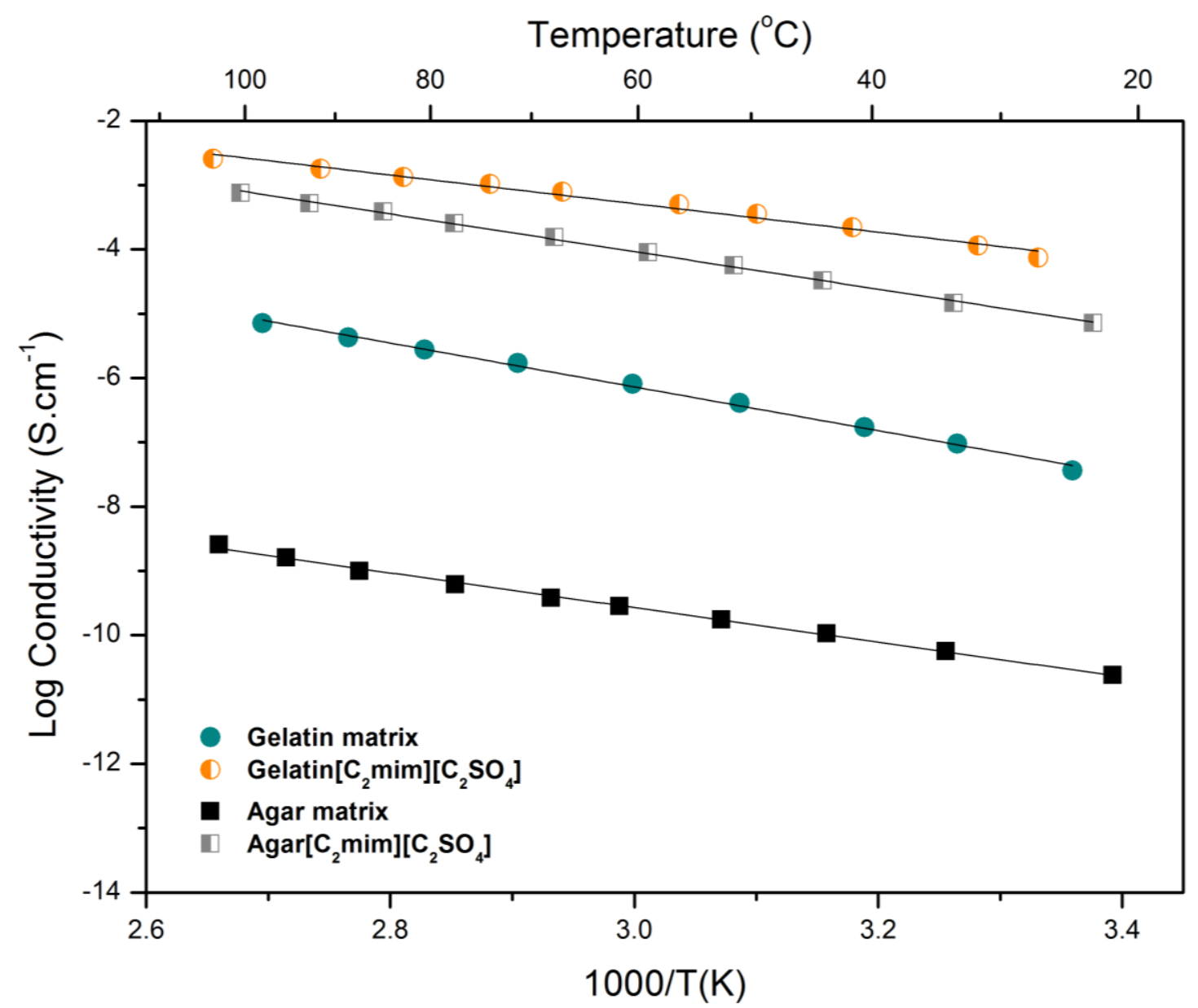

Figure 3. Conductivity curves of different electrolyte systems.

Cyclic voltammetry was employed to evaluate the chemical and electrochemical stability of the solid polymer electrolytes. In the cyclic voltammetric analysis the sweep potential was firstly scanned in the positive direction and then the reversed direction. 
The addition of ionic liquid does not deplete the electrochemical stability of the electrolytes. A very low current flow was observed up to the anodic breakdown voltage, thus supporting for the high purity of the RTIL- based polymer electrolytes.

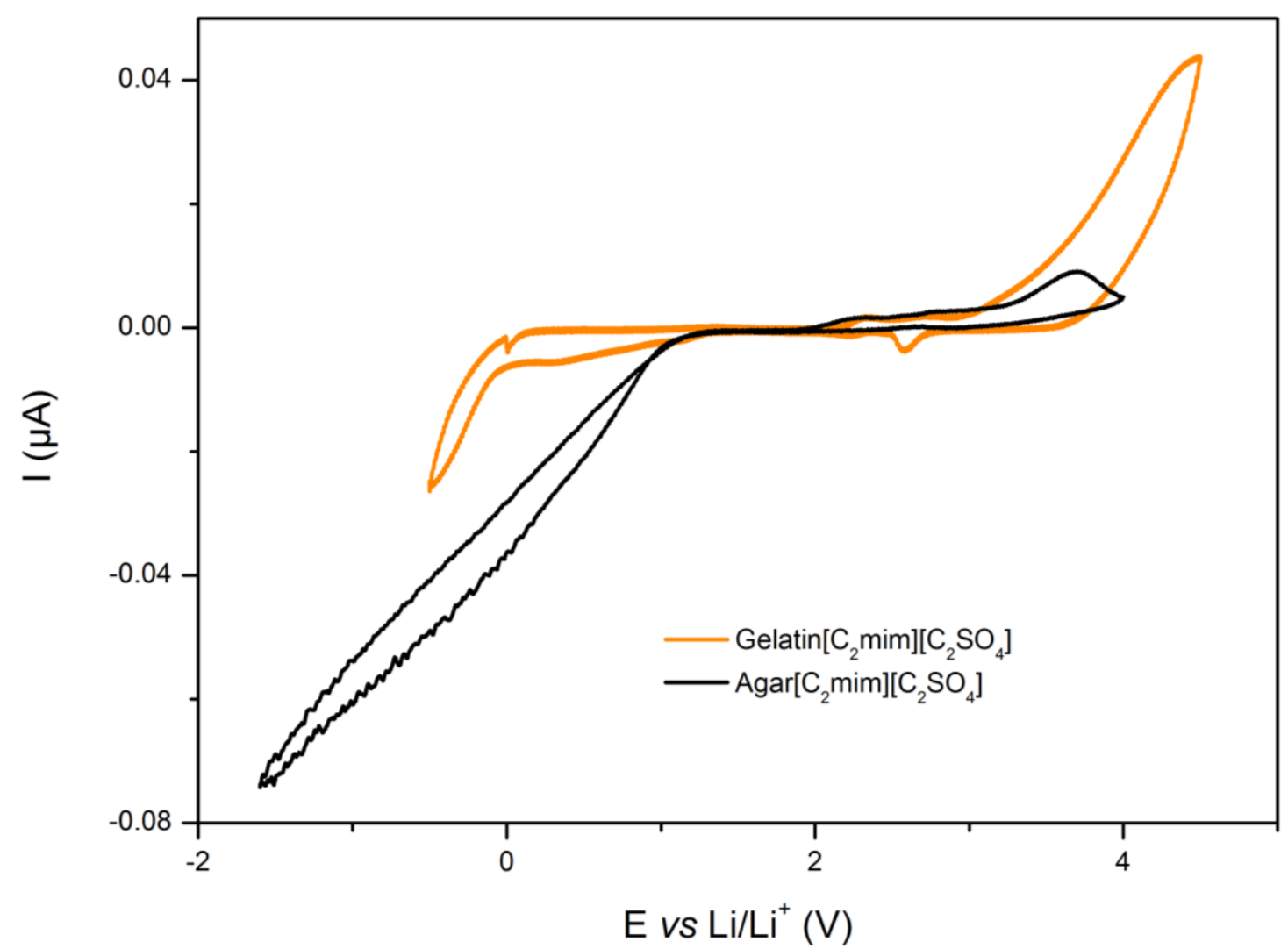

Figure 4. Voltammogram of the polymer electrolytes at a $25 \mu \mathrm{m}$ diameter gold microelectrode versus $\mathrm{Li} / \mathrm{Li}^{+}$. Initial sweep direction is anodic and the sweep rate was $100 \mathrm{mVs}^{-1}$.

Features of a prototype ECD. A preliminary assessment of the potential interest of the samples introduced here as electrolytes in an all solid-state ECDs was performed using the four layer-sandwich configuration (Fig. 5).

The charge density response measured by chronoamperometry $(-2.5 \mathrm{~V} /+2.0 \mathrm{~V} ; 15$ s) of ECD containing solid electrolyte based on gelatin $\left[\mathrm{C}_{2} \mathrm{mim}\right]\left[\mathrm{C}_{2} \mathrm{SO}_{4}\right]$ for the cycles $10^{\text {th }}, 200^{\text {th }}, 400^{\text {th }}$ was obtained (not shown). The charge extraction occurs faster and the ECD is already transparent after applying $+2.0 \mathrm{~V}$ potential during $2 \mathrm{~s}$. This extraction is also faster than that obtained with ECDs containing gelatin without IL (18). 


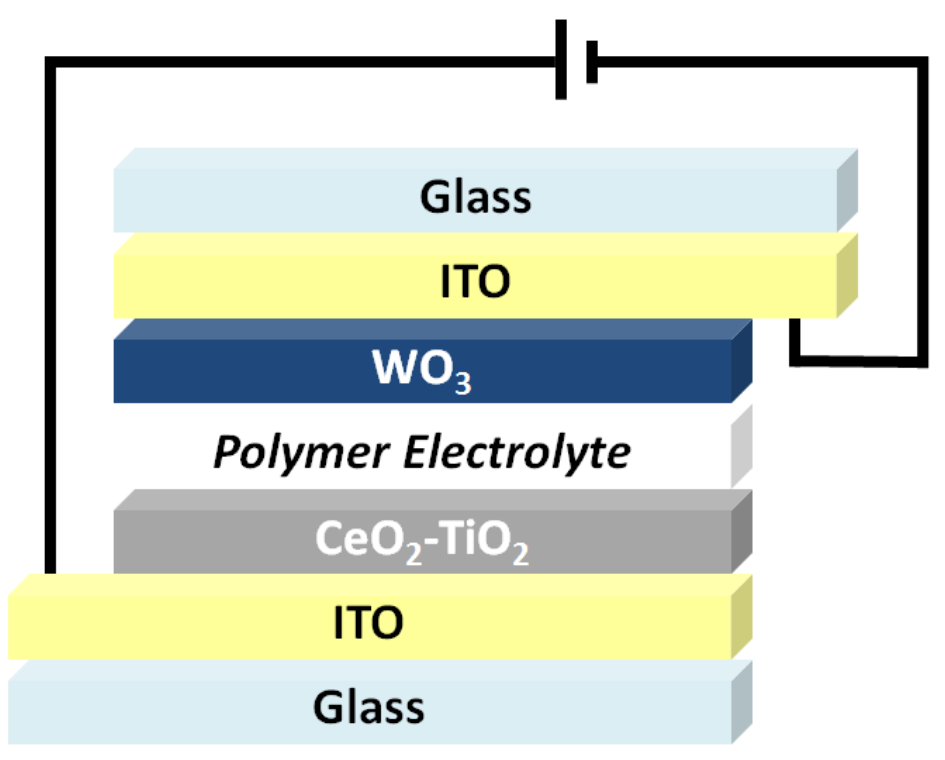

Figure 5. Schematic illustration of the electrochromic structure device.

Electrochemical investigation of $\left[\mathrm{N}_{11} 112(\mathrm{OH})\right]\left[\mathrm{NTf}_{2}\right]$ and $\left[\mathrm{C}_{2} \underline{\operatorname{mim}}\right]\left[\mathrm{C}_{2} \underline{S O}_{4}\right]$ as electrolytes in the study of catalytic behavior of $[\mathrm{Ni}(\mathrm{tmc})] \mathrm{Br}_{2}$

Cyclic voltammetric behavior of $\left[\begin{array}{llll}\mathrm{N}_{1} & 1 & 1 & 2(\mathrm{OH})\end{array}\right]\left[\mathrm{NTf}_{2}\right]$ and $\left[\mathrm{C}_{2} \underline{\mathrm{mim}_{2}}\right]\left[\mathrm{C}_{2} \underline{\mathrm{SO}}_{4}\right]$. The electrochemical stability of the media in the cathodic range is determined by the cation and it was approximately $-2.3 \mathrm{~V} v s \mathrm{Ag} / \mathrm{AgCl}$ for $\left[\begin{array}{llll}\mathrm{N}_{1} & 1 & 1 & 2(\mathrm{OH})\end{array}\right]\left[\mathrm{NTf}_{2}\right]$ and $-2.0 \mathrm{~V} v s$ $\mathrm{Ag} / \mathrm{AgCl}$ for $\left[\mathrm{C}_{2} \mathrm{mim}\right]\left[\mathrm{C}_{2} \mathrm{SO}_{4}\right]$. Therefore both ILs are potentially suitable for the electrochemical reduction of $[\mathrm{Ni}(\mathrm{tmc})] \mathrm{Br}_{2}$ complex which occurs in the potential range from -0.40 to $-1.50 \mathrm{~V} v s \mathrm{Ag} / \mathrm{AgCl}(19,20)$.

Cyclic voltammetric behaviour of $[\mathrm{Ni}(\mathrm{tmc})] \mathrm{Br}_{2}$. The electrochemical behavior of $[\mathrm{Ni}(\mathrm{tmc})] \mathrm{Br}_{2}(\underline{\mathbf{2}})$ was performed in $\left[\mathrm{N}_{1} 1 \mathrm{l}_{2}(\mathrm{OH})\right]\left[\mathrm{NTf}_{2}\right]$ and $\left[\mathrm{C}_{2} \mathrm{mim}\right]\left[\mathrm{C}_{2} \mathrm{SO}_{4}\right]$.

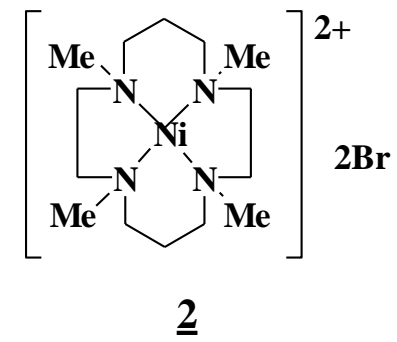

Shown in Fig. 6, curve A, is a cyclic voltammogram obtained with vitreous carbon electrode at $100 \mathrm{mV} \mathrm{s}^{-1}$ for the reduction of $1.0 \mathrm{mM}$ solution of $[\mathrm{Ni}(\mathrm{tmc})] \mathrm{Br}_{2}$ in $\left[\mathrm{N}_{1} 1_{1} 1\right.$ $2(\mathrm{OH})]\left[\mathrm{NTf}_{2}\right]$. The $[\mathrm{Ni}(\mathrm{tmc})]^{2+}$ complex undergoes a reversible one-electron reduction and the values of $E_{p c}$ and $E_{p a}$ are -0.96 and $-0.89 \mathrm{~V}$, respectively. These peak potentials are more negative than those found in DMF (19) and in EtOH (20). Similar results were found for the cyclic voltammetric studies carried out in $\left[\mathrm{C}_{2} \mathrm{mim}\right]\left[\mathrm{C}_{2} \mathrm{SO}_{4}\right]$. 


\section{$\mathrm{E}(\mathrm{V})$ vs $\mathrm{Ag} / \mathrm{AgCl}$}

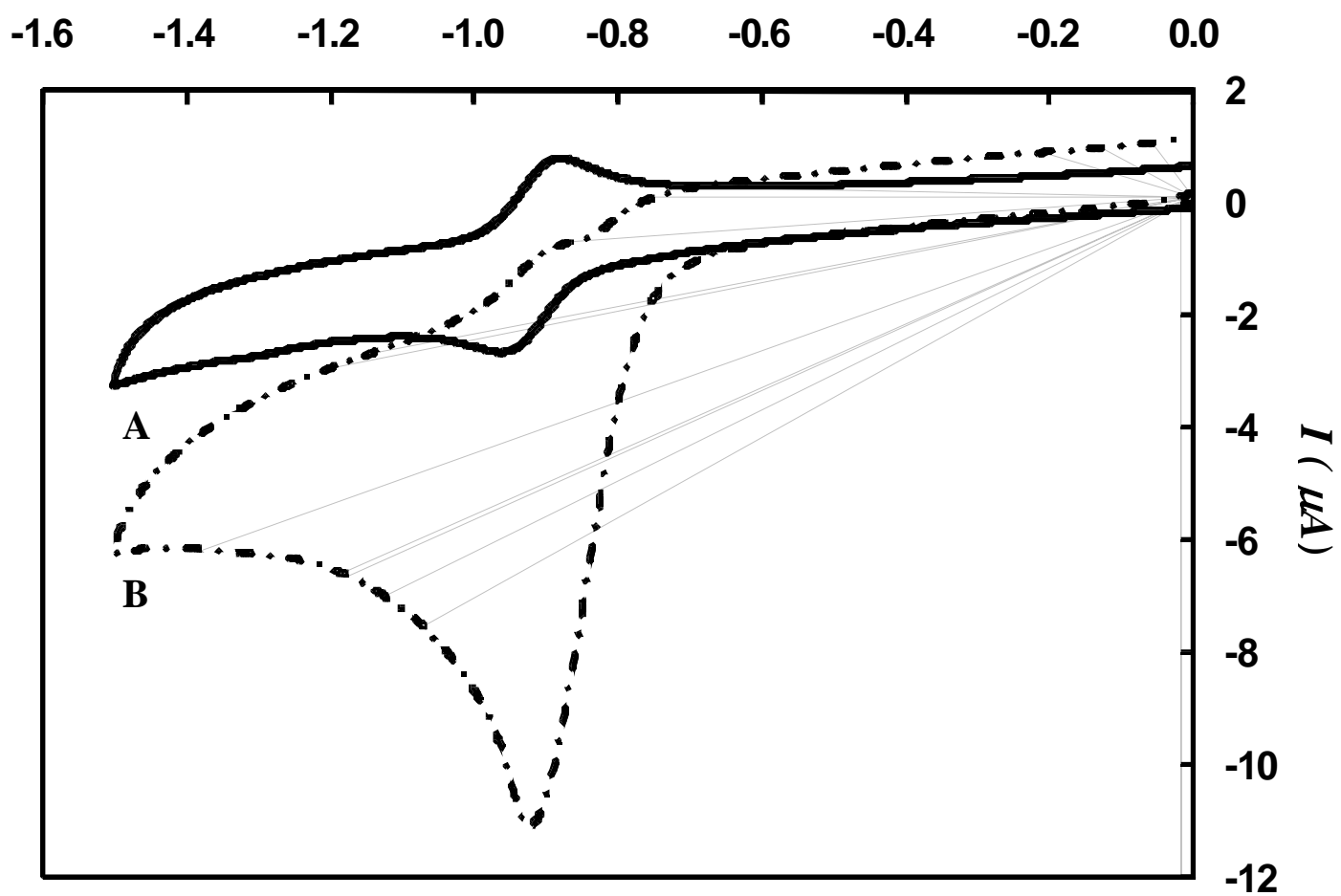

Figure 6. Cyclic voltammograms recorded with a glassy carbon electrode (area $=0.07$ $\mathrm{cm}^{2}$ ) at $100 \mathrm{mV} \mathrm{s}^{-1}$ in $\left[\begin{array}{llllll}\mathrm{N}_{1} & 1 & 1 & 2(\mathrm{OH})\end{array}\left[\mathrm{NTf}_{2}\right]:\right.$ (A) $1,0 \mathrm{mM}\left[\mathrm{Ni}\left(\mathrm{tmc}^{\mathrm{m}}\right)\right] \mathrm{Br}_{2}$; (B) $1,0 \mathrm{mM}$ $[\mathrm{Ni}(\mathrm{tmc})] \mathrm{Br}_{2}$ and $5,0 \mathrm{mM} \underline{\mathbf{1}}$.

The formal potentials were -0.92 and $-0.94 \mathrm{~V} v s \mathrm{Ag} / \mathrm{AgCl}$ in $\left[\mathrm{N}_{1} 11\right.$ $\left[\mathrm{C}_{2} \mathrm{mim}\right]\left[\mathrm{C}_{2} \mathrm{SO}_{4}\right]$, respectively.

The diffusion coefficient of [ $\mathrm{Ni}(\mathrm{tmc})] \mathrm{Br}_{2}$ was determined in both ILs and it was 4.3 $\mathrm{x} 10^{-8} \mathrm{~cm}^{2} \mathrm{~s}^{-1}$ in $\left[\mathrm{N}_{1} 1112(\mathrm{OH})\right]\left[\mathrm{NTf}_{2}\right]$ and $1.8 \times 10^{-7} \mathrm{~cm}^{2} \mathrm{~s}^{-1}$ in $\left[\mathrm{C}_{2} \mathrm{mim}\right]\left[\mathrm{C}_{2} \mathrm{SO}_{4}\right]$, which are much smaller than the value found in DMF $\left(4.7 \times 10^{-6} \mathrm{~cm}^{2} \mathrm{~s}^{-1}\right)$ containing $0.10 \mathrm{M}$ $\mathrm{Et}_{4} \mathrm{NBF}_{4}$ (19). The smaller diffusion coefficient can be attributed to the higher viscosity of the ionic liquids. Furthermore, these values are similar to those reported in microemulsions (21).

Catalytic reduction of ethyl 2-bromo-3-(3',4'-dimethoxyphenyl)-3-propargyloxypropanoate $(\mathbf{1})$ by electrogenerated $[\mathrm{Ni}(\mathrm{tmc})]^{+}$complex. Afterwards, to test the use of electrogenerated $[\mathrm{Ni}(\mathrm{tmc})]+$ as a catalyst, it was carried out the cyclic voltammetric behavior of $[\mathrm{Ni}(\mathrm{tmc})]^{2+}$ complex in the presence of bromoalkoxylated $\underline{\mathbf{1}}$ in both ionic liquids.<smiles>C#CCOC(c1ccc(OC)c(OC)c1)C(Br)C(=O)OCc1ccccc1</smiles> 
Fig. 6, curve B, shows the cyclic voltammogram obtained at $100 \mathrm{mV} \mathrm{s}^{-1}$ for the reduction of $1.0 \mathrm{mM}[\mathrm{Ni}(\mathrm{tmc})]^{2+}$ complex in the presence of $5.0 \mathrm{mM} \underline{\mathbf{1}}$ in $\left[\begin{array}{lll}\mathrm{N}_{1} & 1 & 1\end{array}\right.$ $2(\mathrm{OH})]\left[\mathrm{NTf}_{2}\right]$. It can be seen that the cathodic peak current for the reduction of $[\mathrm{Ni}(\mathrm{tmc})]^{2+}$ complex increases and the anodic peak current is absent. The catalytic current observed is due to the regeneration of $[\mathrm{Ni}(\mathrm{tmc})]^{2+}$ complex after cleavage of the carbon-bromine bond.

Under the same experimental conditions, the direct reduction of $\underline{\mathbf{1}}$ occurs at potentials below $-1.40 \mathrm{~V}$ vs $\mathrm{Ag} / \mathrm{AgCl}$. Similar results were found in the cyclic voltammetric experiments performed in $\left[\mathrm{C}_{2} \mathrm{mim}\right]\left[\mathrm{C}_{2} \mathrm{SO}_{4}\right]$. The data obtained from those experiments at several potential scan rates are presented in Table I. These experimental results suggest that the ionic liquids can be used in synthetic electrochemistry providing a new environmentally media for electrosynthesis without any added supporting electrolyte.

In future work we intend to explore the indirect electroreductive cyclization of bromoalkoxylated derivatives of type $\underline{\mathbf{1}}$ using nickel(II) complexes as catalysts to identify and quantify the products obtained from these catalytic processes in ionic liquids.

TABLE I. Data of the ratio $I_{c} / I_{d}$ obtained from the cyclic voltammetry experiments of $1.0 \mathrm{mM}$ $[\mathrm{Ni}(\mathrm{tmc})] \mathrm{Br}_{2}$ in the presence of $5.0 \mathrm{mM} \underline{\mathbf{1}}$ in different RTILs.

\begin{tabular}{|c|c|c|c|}
\hline \multirow{2}{*}{ RTIL } & \multicolumn{3}{|c|}{$\mathbf{I}_{\mathbf{c}} / \mathbf{I}_{\mathbf{d}}{ }^{\mathbf{a}}$} \\
\hline & $v=50 \mathrm{mV} \mathrm{s}^{-1}$ & $v=100 \mathrm{mV} \mathrm{s}^{-1}$ & $v=200 \mathrm{mV} \mathrm{s}^{-1}$ \\
\hline 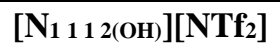 & 5.06 & 6.38 & 5.87 \\
\hline$\left[\mathrm{C}_{2} \mathrm{mim}\right]\left[\mathrm{C}_{2} \mathrm{SO}_{4}\right]$ & 9.01 & 8.54 & 8.06 \\
\hline
\end{tabular}

${ }^{a} I_{c}$ - catalytic peak current intensity of the catalyst in the presence of substrate and $I_{d}$ - peak current intensity of the catalyst in the absence of substrate.

In conclusion: (i) the preliminary results obtained show that the indirect electrochemical cyclization approach in RTILs can be a good alternative to the conventional synthetic methods; (ii) a new gelatin/agar host matrix with ILs guest species has been used to prepare free-standing electrolytes. The materials introduced in this presentation are clearly still at a very preliminary stage in their development and further characterization, including detailed studies of electrochemical stability and the behaviour of prototype electrochromic devices.

\section{Acknowledgements}

The authors are pleased to acknowledge the financial support provided by the University of Minho and the Fundação para a Ciência e Tecnologia (contracts project $n^{\circ}$ F-COMP-01-0124-FEDER-022716, ref $^{\text {a }}$ FCT PEst-C/QUI/UI0686/2011, FEDERCOMPETE, FCT-Portugal, PTDC/CTM-NAN/121274/2010 and PEstOE/EQB/LA0004/2011) for laboratory equipment and research staff. The authors are also indebted to CNPq, FAPESP and CAPES, for the financial support given to this research. 


\section{References}

1. J. Wang, H. R. Li, C. M. Wang and J. Hui, Chem. Commun., 17, 1938 (2004).

2. M. J. Earle, J. M. S. S. Esperança, M. A. Gilea, J. N. C. Lopes, L. P. N. Rebelo, J. W. Magee, K. R. Seddon and J. A. Widegren, Nature, 439, 831 (2006).

3. M. Smiglak, W. M. Reichert, J. D. Holbrey, J. S. Wilkes, L. Y. Sun, J. S. Thrasher, K. Kirichenko, S. Singh, A. R. Katritzky and R. D. Rogers, Chem. Commun., 24, 2554 (2006).

4. J. Yoshida, K. Kataoka, R. Horcajada and A. Nagaki, Chem. Rev., 108, 2265 (2008).

5. B. K. Sweeny and D. G. Peters, Electrochem. Commun., 3, 712 (2001).

6. H. Ohno, Electrochemical Aspects of Ionic Liquids, $2^{\text {nd }}$ Ed., John Wiley \& Sons, Inc., New Jersey (2011).

7. M. M. Silva, P. C. Barbosa, L. C. Rodrigues, A. Gonçalves, C. Costa and E. Fortunato, Opt. Mater., 32, 719 (2010).

8. A. J. L. Costa, M. R. C. Soromenho, K. Shimizu, I. M. Marrucho, J. M. S. S. Esperança, J. N. C. Lopes, L. P. N. Rebelo, Chem. Phys. Chem., 13, 1902 (2012).

9. E. Raphael, C. O. Avellaneda, M. A. Aegerter, M. M. Silva and A. Pawlicka, Mol. Cryst. Liq. Cryst., 554, 264 (2012).

10. E. Raphael, C. O. Avellaneda, B. Manzolli and A. Pawlicka, Electrochim. Acta, 55, 1455 (2010).

11. K. L Vieira and D. G. Peters, J. Electroanal. Chem., 196, 93 (1985).

12. C. Berthier, W. Gorecki, M. Minier, M. Armand, J. M. Chabagno and P. Rigaud, Solid State Ionics, 11, 91 (1983).

13. B. Singh and S. S. Sekhon, J. Phys. Chem. B, 109(34), 16539 (2005).

14. D. F. Vieira and A. Pawlicka, Electrochim. Acta, 55, 1489 (2010).

15. Y. Akgol, C. Hofmann, Y. Karatas, C. Cramer, H. D. Wiemhofer and M.J. Schonhoff, Phys. Chem. B, 111, 8532 (2007).

16. A. S. Shaplov, E. I. Lozinskaa, D. O. Ponkratov, I. A. Malyshkina, F. Vidal, Pierre-Henri Aubert, O. V. Okatova, G. M. Pavlov, L. I. Komarova, C. Wandre, Y. S. VgodskiI, Electrochim. Acta, 57, 74 (2011).

17. F. M. Gray, Solid Polymer Electrolytes: Fundamentals and Technological Applications, VCH Publishers, New York (1991).

18. A. Al-Kahlout, D. Vieira, C. O. Avellaneda, E. R. Leite, M. A. Aegerter and A. Pawlicka, Ionics, 16, 13 (2010).

19. A. P. Esteves, D. M. Goken, J. L. Klein, M. A. Lemos, M. J. Medeiros and D. G. Peters, J. Org. Chem., 68, 1024 (2003).

20. E. Duñach and M. J. Medeiros, Electrochim. Acta, 53, 4470 (2008).

21. A.P. Esteves, C. S. Neves, M. J. Medeiros and D. Pletcher, J. Electroanal. Chem., 614, 131 (2008). 